\section{Extent of integration of the Information Communication Technology in teaching at selected public elementary schools in the Division of Pasig City, District IV: Indices for an improved instructional delivery}

Torres, Marites $₫$

Emilio Aguinaldo College, Philippines (maritesc.torres@deped.gov.ph)

Received: 30 March 2021

Available Online: 24 June 2021
Revised: 16 May 2021 DOI: $10.5861 /$ ijrse. 2021.657

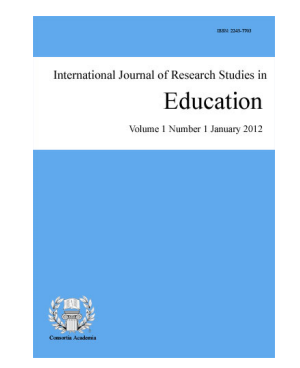

ISSN: 2243-7703 Online ISSN: 2243-7711

OPEN ACCESS

\title{
Abstract
}

This study determined the integration of ICT in teaching by the teachers in selected public elementary schools at District IV in the Division of Pasig City, assessed by the heads, and teachers themselves. The method used was descriptive to collect quantitative information by setting up a condition that allowed respondent to answer the survey questionnaire through a checklist about integration on instructional technologies and capabilities of their school. In this study, the heads and the teachers in selected public elementary schools at District IV of the Division of Pasig City-Ninoy Aquino Pilot Community Elementary School (NAES), and Manggahan Elementary School (MES), were tasked to answer the research questions. There were 27 heads and 134 teachers who partook in assessing the research problems. The majority of the respondents were mature and old enough to handle their students. It also shows that since they were mature, they were confident and more experienced than the beginner teachers. Furthermore, most head teachers and teachers were females; thus' they were all guided by their maternal instinct in teaching their students. Most of the teachers considered Graduate School as part of their profession. They are all continuing their education for them to gain more knowledge about teaching. There are 22 percent of the respondents who needs to be encourage in attending training/seminars regarding ICT. The extent of ICT integration required by the two groups of respondents classified as to entry, adaptation and appropriation rated as Agree. While in terms of adoption and invention, it ranked as Highly Agree. There is a significant difference between the assessments of the two groups of respondents on integrating ICT in teaching. There is a significant difference between the extent of teacher's integration when grouped according to the teacher's age, sex and number of training/seminars attended regarding ICT. However, when it comes to highest educational attainment, there is no significant difference.

Keywords: integration, instructional delivery, ICT, appropriation, adoption 


\section{Extent of integration of the Information Communication Technology in teaching at selected public elementary schools in the Division of Pasig City, District IV: Indices for an improved instructional delivery}

\section{Introduction}

The Integration of Information Communication Technology in the School has not to do with simple improvements of the traditional instruction, but to a radically new teaching; a change from the traditional instruction model of knowledge, transmitting towards autonomous, active and collaborative learning through pupils' engagement in ICT-based learning environments and shared learning resources. The grade of integration is set upon the cooperation between infrastructures, teacher motivation, introduction and development of education that is efficient for any activities designed to give knowledge and has relevance with student learning. A teacher should employ and involve the scholarly person in teaching, learning processes in integrating ICT for both gaining of information and using it. Information Communication Technology (ICT) should be used in educational activities, learning to access info, keep learning and communicate understanding. The significance of using technology is to educate the pupils about the importance of dedicating their knowledge for flexibility, productivity, competitiveness and developing $21^{\text {st }}$ century skills in teaching to strengthen pupil's learning. As Confucius quoted "I hear and I forget, I visualize and I remember, I do, and I understand."

Effective teaching and learning are created when ICT is embedded into the classroom environment. Students take on greater responsibility for their knowledge when they use ICT to work more independently and effectively. In addition, ICT offers assignments suited to individual needs and makes it easier to coordinate their learning, using, for example, digital portfolios. In addition, the role of ICT helps the teachers to create and design different learning styles or strategies in the classroom, to use learning materials that need sensory stimulation such as visualizing, hearing and the concrete and abstract materials where learners can easily understand and retain data. Using ICT, teachers can access information easily using different educational websites, create knowledge, and use spreadsheets, word processors and graphic tools.

Developments in Information and Communication Technologies (ICTs) have touched all sectors of society, including the breeding sector. In basic education, the application of ICTs is already changing teaching and interpretation processes. The information processing system as an educational tool arrived in shoals with a great deal of prior enthusiastic claims about how it could be used to reform education by coming to schools more efficient and productive, by transforming teaching and scholarship into an engaging and active process connected to material life and preparing citizen for their future study at the same time. Integration of ICTs in the affairs of any organization is a complex procedure that needs to be fully conceptualized and defined from the root. Nevertheless, this is not the case in many higher learning institutions in developing countries. Most of them have embraced the ICT integration process without clear plans to lead the direction. Specifying the institution's ICT policy and strategic plan will help provide a framework for the growth and execution of specific ICT projects. The diversity and competing interests of different stakeholders in the institution should be picked out when developing ICT policy and a strategic design.

\subsection{Significance of the study}

The role of information and communication technology (ICT) such as Internet applications, CD-ROMs, video engineering and various computer attachments and software programs have made many changes in guild. These modifications have not just been technical, but more importantly, of a morphological nature. Many of the major introductions of our society have changed. The way we inhabit our daily lives has been affected. Nevertheless, the impact on education may begin to be felt as teachers incorporate this new applied science into 
their instruction. In the early levels of using ICT in educational activity, expecting teachers' experiences in the basic education in the forefront provides some hints as to what possibilities and this novel technology may present problems.

This study would be significant to the following stakeholders: Administrators/ School Heads, the outcomes of this study would be for Integration of Information and Communication Technology which will benefit the schools; improve the instructional strategy of teachers using computers. For Teachers, the output of this study would make the teachers aware of Information Communication Technology to enhance instructional strategy, teaching competence, and student performance. Also, computers could help teachers in terms of information access and research. Moreover, they will also be aware of their weaknesses and strengths about computers. For Parents, continuous support to upgrade the technological expertise of the teachers would result in a better teaching-learning process for their children. Pupils, they will benefit from this study because they are the ultimate recipients of Integrated Information and Communication Technology provided to the teachers. For Researchers, the results of the study can be a basis for other researchers for future references. It would also give them an idea of the importance of computers in the research process. They may include other variables to deepen the study of Information and Communication Technology.

\section{Methodology}

The descriptive survey method was used to collect quantitative information by setting up a condition that allowed respondents to answer the survey questionnaire through a checklist about integration on instructional technologies and capabilities of their school. The three main purposes of the research were to be described, analyzed and validated findings. Description emerged following creative exploration and served to organize the findings to fit them with explanations, and test or validate them. These data collected could then be used to recommend integrated technology in improving teaching strategies.

In this study, the heads and the teachers in selected public elementary schools at District IV of the Division of Pasig City-Ninoy Aquino Pilot Community Elementary School (NAES), and Manggahan Elementary School (MES), were tasked to answer the research questions. A total of 27 heads and 134 teachers in those schools were used to answer the specific questions. The instrument employed a standardized questionnaire. The instrument contained two (2) parts. The first part determined the demographic profile of the heads and teacher-respondents as to age, sex, highest educational attainment, and trainings / seminars attended related to ICT.

The second part determined the extent of ICT integration in teaching at selected public elementary schools as assessed by the two groups of respondents, in terms of the stages of technology integration such as Entry, Adoption, Adaptation, Appropriation, and Invention. First, the researchers wrote a letter to request an endorsement from the Schools Division Office of Pasig City. After which, the researcher approached the principals of the two (2) target locales to administer the research instrument. All the needed data should have been gathered within at least one (1) week. Upon receipt of the survey returns, the researcher tallied and coded the responses and treatment of the gathered data followed suit.

The simple frequency count and Percentage were used as statistical tools in treating the data to give meaning to the data gathered. Frequency and Percentage (\%) will be used to determine the respondent's profile in terms of demographic variables (age, sex, highest educational attainment and several trainings/ seminars attended related to ICT). Weighted Mean ( $x$ ) was used to interpret the mean perceptions of the extent of integration of ICT in teaching as assessed by the two groups of respondents. Chi-square $(\chi 2)$ statistic is a test that measures how expectations compare to actual observed data (or model results).

\section{Findings and discussions}

This study determined the integration of Information Communication Technology in teaching by the teachers in selected public elementary schools at District IV in the Division of Pasig City, as assessed by the 
Torres, M.

heads, and teachers themselves. The results of the study can be used as indices for improving instructional delivery. The descriptive survey method was used to collect quantitative information by setting up a condition that allowed respondents to answer the survey questionnaire through a checklist about integration on instructional technologies and capabilities of their school. In this study, the heads and the teachers in selected public elementary schools at District IV of the Division of Pasig City-Ninoy Aquino Pilot Community Elementary School (NAES), and Manggahan Elementary School (MES), were tasked to answer the research questions. A total of 27 heads and 134 teachers in those schools were randomly picked to answer the specific questions.

\subsection{The profile of the teacher}

\section{Table 1}

Frequency and percentage distribution of respondents' profile in terms of age

\begin{tabular}{cccccccc}
\hline \multirow{2}{*}{ Age } & \multicolumn{2}{c}{ Head Teachers } & \multicolumn{2}{c}{ Teachers } & \multicolumn{2}{c}{ Total } \\
& $f$ & $\%$ & $f$ & $\%$ & $f$ & $\%$ \\
\hline 25-below & 1 & 4 & 7 & 5 & 8 & 5 \\
26-35 & 4 & 15 & 32 & 24 & 36 & 22 \\
36-above & 22 & 81 & 95 & 71 & 117 & 73 \\
& Total & 27 & 100 & 134 & 100 & 161 & 100.0 \\
\hline
\end{tabular}

Table 1 showed the frequency and percentage distribution of the teachers and head teacher respondents in terms of age. Majority of the respondents were 36 years old and above with a frequency of 117 or 73 percent. Thirty-six or 22 percent belong to the age bracket of 26 to 35 years old. Only 8 or 5 percent were 25 years old and below. The table implied that the majority of the respondents were mature and old enough to handle their students. It also shows that since they were mature, they were confident and more experienced than the beginner teachers.

Table 2

Frequency and percentage distribution of respondents' profile in terms of gender

\begin{tabular}{cccccccc}
\hline \multirow{2}{*}{ Sex } & \multicolumn{2}{c}{ Head Teachers } & \multicolumn{2}{c}{ Teachers } & \multicolumn{2}{c}{ Total } \\
& $f$ & 6 & $\%$ & $f$ & $\%$ & $f$ & $\%$ \\
\hline Male & & 22 & 16 & 12 & 22 & 14 \\
Female & & 21 & 78 & 118 & 88 & 139 & 86 \\
& Total & 27 & 100 & 134 & 100 & 161 & 100 \\
\hline
\end{tabular}

Table 2 presented the frequency and percentage distribution of the teachers and head teacher respondents in terms of sex. Of the 161 respondents, 139 or 86 were females. Only 22 or 14 were males. It can be concluded that majority of the head teachers and teachers were females thus they were all guided by their maternal instinct in teaching their students.

Table 3

Frequency and percentage distribution of respondents' profile in terms of highest educational attainment

\begin{tabular}{|c|c|c|c|c|c|c|}
\hline \multirow{2}{*}{ Highest Educational Attainment } & \multicolumn{2}{|c|}{ Head Teachers } & \multicolumn{2}{|c|}{ Teachers } & \multicolumn{2}{|c|}{ Total } \\
\hline & $f$ & $\%$ & $f$ & $\%$ & $f$ & $\%$ \\
\hline Doctorate Degree & 2 & 7 & - & - & 2 & 1 \\
\hline Units in Doctorate & 4 & 15 & 10 & 8 & 14 & 9 \\
\hline Master's Degree & 16 & 59 & 48 & 36 & 64 & 40 \\
\hline Units in Master & 5 & 19 & 54 & 40 & 59 & 36 \\
\hline Bachelor's Degree & - & - & 22 & 16 & 22 & 14 \\
\hline Total & 27 & 100 & 134 & 100 & 161 & 100 \\
\hline
\end{tabular}

Table 3 discussed the distribution of the respondents by their highest educational attainment. Sixty-four or 40 percent of the respondents were graduate of master's degree while fifty-nine or 36 however were currently 
Extent of integration of the ICT in teaching at selected public elementary schools in the Division of Pasig City taking units in master's degree. Twenty-two or 14 percent were graduate of bachelor's degree. Fourteen or 9 percent of the respondents were taking units in Doctorate Degree while 2 or 1 percent have already graduated with Doctorate Degree. The table showed that most of the teachers considered Graduate School as part of their profession. They were all continuing their education for them to gain more knowledge about teaching.

\section{Table 4}

Frequency and percentage distribution in terms of number of trainings/seminars attended related to ICT

\begin{tabular}{|c|c|c|c|c|c|c|}
\hline \multirow{2}{*}{$\begin{array}{c}\text { Number of Trainings/Seminars } \\
\text { Attended Related to ICT }\end{array}$} & \multicolumn{2}{|c|}{ Head Teachers } & \multicolumn{2}{|c|}{ Teachers } & \multicolumn{2}{|c|}{ Total } \\
\hline & $f$ & $\%$ & $f$ & $\%$ & $f$ & $\%$ \\
\hline $0-1$ & 1 & 4 & 34 & 25 & 35 & 22 \\
\hline $2-3$ & 10 & 37 & 52 & 39 & 62 & 38 \\
\hline $4-5$ & 11 & 41 & 27 & 20 & 38 & 24 \\
\hline 6 and above & 5 & 18 & 21 & 16 & 26 & 16 \\
\hline Total & 27 & 100 & 134 & 100 & 161 & 100 \\
\hline
\end{tabular}

A number of training or seminars attended related to Information Communication Technology (ICT) were discussed in Table 4. Of the 161 respondents, 62 or 38 percent have claimed that they attended 2 to 3 training/seminars regarding ICT. Thirty-eight or 24 percent have attended 4-5 training/seminars regarding ICT, followed by those who attended only 1 training with a frequency of 35 or 22 percent. The remaining respondents have attended 6 and above training/seminars regarding ICT comprising 26 or 16 percent of the respondents. There were 22 percent of the respondents who needed to be encouraged in attending training/seminars regarding ICT.

\subsection{The extent of integration of ICT as assessed by the two groups of respondents}

\section{Table 5}

Extent of integration of ICT as needed by the two groups of respondents classified as to entry

\begin{tabular}{|c|c|c|}
\hline Entry & Mean & $\begin{array}{c}\text { Verbal } \\
\text { Interpretation }\end{array}$ \\
\hline $\begin{array}{l}\text { 1. uses common tools (blackboards, textbooks, workbooks, ditto sheets, and } \\
\text { overhead projectors) }\end{array}$ & 3.68 & Highly Agree \\
\hline 2. Creates combination to support (lecture, recitation, seatwork) & 3.66 & Highly Agree \\
\hline 3. replaces blackboard to whiteboard & 2.53 & Agree \\
\hline 4. uses instructional technology & 3.66 & Highly Agree \\
\hline 5. experiences computer technology & 3.67 & Highly Agree \\
\hline Composite Mean & 3.44 & Agree \\
\hline
\end{tabular}

Legend: 3.51-4.00 Highly Agree; 2.51-3.50 Agree; 1.51-2.50 Moderately Agree; 1.00-1.50 Disagree.

Table 5 conferred the extent of integration of ICT as needed by the two groups of respondents classified as to entry. The overall Mean resulted to 3.44 which is interpreted as Agree. The respondents agree to replace blackboard to whiteboard ( $\mathrm{WM}=2.53$ ). However, they expressed a highly agree with regards to uses common tools (blackboards, textbooks, workbooks, ditto sheets, and overhead projectors) $(\mathrm{WM}=3.68)$, creates combination to support (lecture, recitation, seatwork) $(\mathrm{WM}=3.66)$, uses instructional technology $(\mathrm{WM}=3.66)$ and experiences computer technology $(\mathrm{WM}=3.67)$.

The findings were congruent to the study of Grabe (2017), technologies can act a role in student skills, motivation, and cognition. They claim that ICT can be "utilized to give information to students and help them complete learning projects “. Information and Communications Technology (ICT) has gone through innovations and transformed our society that has totally changed the way people think, work and live. As part of this, schools and other educational institutions which are supposed to prepare students to live in "a knowledge society" need to consider ICT integration in their curriculum (Ghavifekr, Afshari, \& Amla Salleh, 2016). In conjunction with preparing students for the current digital era, teachers are the key players in using ICT in their daily classrooms. This is due to the capability of ICT in providing dynamic and proactive teaching-learning environments (Arnseth 
Torres, M.

\& Hatlevik, 2016)

Table 6

Extent of integration of ICT as needed by the two groups of respondents classified as to adaptation

\begin{tabular}{|c|c|c|}
\hline Adaptation & Mean & $\begin{array}{c}\text { Verbal } \\
\text { Interpretation }\end{array}$ \\
\hline 1. engages student in higher-order learning & 3.55 & Highly Agree \\
\hline 2. uses word processors for assignments & 3.19 & Agree \\
\hline 3. composes pupil stories or activity directly on computer & 3.13 & Agree \\
\hline 4. leads the new strategies for instruction, feedback and evaluation & 3.33 & Agree \\
\hline 5. changes the quality engagement of pupils with technology & 3.32 & Agree \\
\hline Composite Mean & 3.30 & Agree \\
\hline
\end{tabular}

Legend: 3.51-4.00 Highly Agree; 2.51-3.50 Agree; 1.51-2.50 Moderately Agree; 1.00-1.50.

The respondents agree to use word processors for assignments (WM $=3.19$ ), compose pupil stories or activity directly on computer ( $\mathrm{WM}=3.13$ ), lead the new strategies for instruction, feedback and evaluation (WM $=3.33$ ) and change the quality engagement of pupils with technology ( $\mathrm{WM}=3.32)$. On the other hand, they highly agree to engage students in higher-order learning $(\mathrm{WM}=3.30)$.

The results of the findings were connected to the book of Shelly and Cashman (2014) entitled "Teacher's Discovering Computers", cited that teacher can increase their productivity significantly by using word processing software to create documents such as lesson plans, handouts, parent communications and pupils' tests. Teachers use word processing to transform paper documents into electronic form to eliminate abundant works. Spreadsheets are like teacher class records. Also, Cashman defines education as all the experiences of a learner has under the supervision or guidance of teachers which consists of a plan or written document that includes a series of required outcomes.

\section{Table 7}

Extent of integration of ICT as needed by the two groups of respondents classified as to adoption

\begin{tabular}{|c|c|c|c|}
\hline Adoption & & Mean & $\begin{array}{c}\text { Verbal } \\
\text { Interpretation }\end{array}$ \\
\hline 1. struggles to accommodate the technology & & 3.63 & Highly Agree \\
\hline 2. balance the concern uses of computer & & 3.52 & Highly Agree \\
\hline $\begin{array}{l}\text { 3.adopts new electronic technology } \\
\text { (text-based, drill-and-practice instruction) }\end{array}$ & & 3.59 & Highly Agree \\
\hline 4. masters computer skill and ideas & & 3.34 & Agree \\
\hline 5. formulates management strategies & & 3.45 & Agree \\
\hline & Composite Mean & 3.51 & Highly Agree \\
\hline
\end{tabular}

Legend: 3.51-4.00 Highly Agree; 2.51-3.50 Agree; 1.51-2.50 Moderately Agree; 1.00-1.50

In terms of adoption, it resulted in an overall mean of 3.51 and interpreted as highly agree. The respondents highly agree that the following needs were needed by the two groups of respondents to extent the integration of ICT in terms of adoption; struggles to accommodate the technology ( $\mathrm{WM}=3.63$ ); balance the concern uses of computer (WM = 3.52) and adopts new electronic technology (text-based, drill-and-practice instruction) $(\mathrm{WM}=$ 3.59). On the other hand, the respondents also agree to master's computer skills and ideas $(\mathrm{WM}=3.34)$ and formulate management strategies in terms of adoption $(\mathrm{WM}=3.45)$.

The findings were congruent to the study of Osborne and Collins (2014) because they claimed that ICT can be used to present data to students and help them complete learning tasks. New technologies may also serve to increase student motivation (Osborne \& Collins, 2014), facilitate clearer thinking, and develop an interpretation, skills will data (Newton \& Rogers, 2017). 
Extent of integration of the ICT in teaching at selected public elementary schools in the Division of Pasig City

Table 8

Extent of integration of ICT as needed by the two groups of respondents classified as to appropriation

\begin{tabular}{|c|c|c|}
\hline Appropriation & Mean & $\begin{array}{c}\text { Verbal } \\
\text { Interpretation }\end{array}$ \\
\hline 1. hinges on teacher mastery of technology & 3.05 & Agree \\
\hline 2. understands technology & 3.32 & Agree \\
\hline $\begin{array}{l}\text { 3. accommodates more ambitious class projects (video editing, } \\
\text { PowerPoint, etc.) }\end{array}$ & 3.41 & Agree \\
\hline 4. operates computer proficiently & 3.29 & Agree \\
\hline 5. points where computers become natural tools & 3.37 & Agree \\
\hline Composite Mean & 3.29 & Agree \\
\hline
\end{tabular}

Legend: 3.51-4.00 Highly Agree; 2.51-3.50 Agree; 1.51-2.50 Moderately Agree; 1.00-1.50 Disagree.

Table 8 illustrated the extent of integration of ICT as needed by the two groups of respondents classified as to appropriation. The computed overall Mean resulted to 3.29 and interpreted as agree. The respondents agree that the following should be integrated; hinges on teacher mastery of technology $(\mathrm{WM}=3.05)$, understands technology ( $\mathrm{WM}=3.32$ ), accommodates more ambitious class projects (video editing, PowerPoint, etc.) $(\mathrm{WM}=$ $3.41)$, operates computer proficiently $(\mathrm{WM}=3.37)$ and points where computers become natural tools $(\mathrm{WM}=$ $3.29)$.

Casiano (2017) also stated that "computer has a capability for administrative and managerial users namely: easing enrollment procedures, preparing transcript of records, recording grades, paying school fees, and others, as well as for teaching purposes. Moreover, it has given way to the development of multi-media which is creating an exciting and very real interactive learning environment." Readiness and interest of teachers and school heads is the most critical factor for successful implementation of integrated technology. The teacher must fully equip and up to the task. Teacher must harness the full potentials of technology to improve learning outcomes.

\section{Table 9}

Extent of integration of ICT as needed by the two groups of respondents classified as to invention

\begin{tabular}{lcc}
\multicolumn{1}{c}{ Invention } & Mean & $\begin{array}{c}\text { Verbal } \\
\text { Interpretation }\end{array}$ \\
\hline $\begin{array}{l}\text { 1. demonstrates using technology (PowerPoint, Excel, etc.) } \\
\text { 2. uses technology in activities }\end{array}$ & 3.58 & $\begin{array}{c}\text { Highly Agree } \\
\text { 3. disposes to view learning as an active, creative, and socially } \\
\text { interactive }\end{array}$ \\
$\begin{array}{l}\text { 4. implements changes in teaching } \\
\text { 5. invents interdisciplinary activities on technology } \\
\text { Composite Mean }\end{array}$ & 3.47 & Agree \\
\hline Legend: 3.51-4.00 Highly Agree; 2.51-3.50 Agree; 1.51-2.50 Moderately Agree; 1.00-1.50 Disagree. & Highly Agree
\end{tabular}

Regarding the invention, it resulted in an overall mean of 3.50 and interpreted as highly agree. The respondents highly agree that the following integration in terms of invention is needed; demonstrates using technology (PowerPoint, Excel, etc.) (WM = 3.58), uses technology in activities (WM = 3.53), implements changes in teaching ( $\mathrm{WM}=3.51)$ However, they decided to agree to dispose to view learning as an active, creative, and socially interactive $(\mathrm{WM}=3.47)$ and invents interdisciplinary activities on technology $(\mathrm{WM}=$ 3.43).

The findings were congruent to Ruttan and Wouter (2014) stated that "demonstrated that the employment of computer situations while teaching in the classroom will not be successful unless teachers have the necessary suits and information to implement them efficiently". New technologies hold the potential to support teaching across the curriculum and provide chances for effective communication between teachers and pupils in ways that have not been possible earlier. ICT in education has the potential to be influential in bringing about changes in ways of educational activity. 
Torres, M.

\section{Table 10}

Summary of the extent of integration of ICT as needed by the two groups of respondents

\begin{tabular}{lcc}
\hline \multicolumn{1}{c}{ Extent of Integration of ICT } & Mean & $\begin{array}{c}\text { Verbal } \\
\text { Interpretation }\end{array}$ \\
\hline 1. Entry & 3.44 & Agree \\
2. Adaptation & 3.30 & Agree \\
3. Adoption & 3.51 & Highly Agree \\
4. Appropriation & 3.29 & Agree \\
5. Invention & 3.50 & Highly Agree \\
\hline Legend: 3.51-4.00 Highly Agree; 2.51-3.50 Agree; 1.51-2.50 Moderately Agree; 1.00-1.50 Disagree.
\end{tabular}

Table 10 illustrated the extent of integration of ICT as needed by the two groups of respondents classified as to entry, adaptation, and appropriation rated as Agree. Meanwhile in terms of adoption and invention, it rated as Highly Agree.

3.3 The significant difference between the assessments of the two groups of respondents on the extent of integration of ICT in teaching

\section{Table 11}

Differences between the assessments of respondents on the extent of integration of ICT in teaching

\begin{tabular}{|c|c|c|c|c|c|c|c|}
\hline $\begin{array}{c}\text { Extent of Integration } \\
\text { of ICT in Teaching }\end{array}$ & Item & Mean & SD & t-value & Sig & Decision & Interpretation \\
\hline \multirow{5}{*}{ 1. Entry } & 1 & 3.68 & .543 & \multirow{5}{*}{100.286} & \multirow{5}{*}{.000} & \multirow{5}{*}{ Rejected } & \multirow{5}{*}{ Significant } \\
\hline & 2 & 3.66 & .612 & & & & \\
\hline & 3 & 2.53 & 1.173 & & & & \\
\hline & 4 & 3.66 & .593 & & & & \\
\hline & 5 & 3.67 & .522 & & & & \\
\hline \multirow{5}{*}{ 2. Adaptation } & 1 & 3.55 & .547 & \multirow{5}{*}{78.189} & \multirow{5}{*}{.000} & \multirow{5}{*}{ Rejected } & \multirow{5}{*}{ Significant } \\
\hline & 2 & 3.19 & .825 & & & & \\
\hline & 3 & 3.13 & .726 & & & & \\
\hline & 4 & 3.33 & .610 & & & & \\
\hline & 5 & 3.32 & .587 & & & & \\
\hline \multirow{5}{*}{ 3.Appropriation } & 1 & 3.63 & .248 & \multirow{5}{*}{47.936} & \multirow{5}{*}{.000} & \multirow{5}{*}{ Rejected } & \multirow{5}{*}{ Significant } \\
\hline & 2 & 3.52 & 3.537 & & & & \\
\hline & 3 & 3.59 & 2.276 & & & & \\
\hline & 4 & 3.34 & .681 & & & & \\
\hline & 5 & 3.45 & .580 & & & & \\
\hline \multirow{5}{*}{ 4. Adoption } & 1 & 3.05 & .828 & \multirow{5}{*}{81.265} & \multirow{5}{*}{.000} & \multirow{5}{*}{ Rejected } & \multirow{5}{*}{ Significant } \\
\hline & 2 & 3.32 & .629 & & & & \\
\hline & 3 & 3.41 & .666 & & & & \\
\hline & 4 & 3.29 & .646 & & & & \\
\hline & 5 & 3.37 & .556 & & & & \\
\hline \multirow{5}{*}{ 5. Invention } & 1 & 3.58 & .532 & \multirow{5}{*}{89.371} & \multirow{5}{*}{.000} & \multirow{5}{*}{ Rejected } & \multirow{5}{*}{ Significant } \\
\hline & 2 & 3.53 & .570 & & & & \\
\hline & 3 & 3.47 & .548 & & & & \\
\hline & 4 & 3.51 & .571 & & & & \\
\hline & 5 & 3.43 & .599 & & & & \\
\hline \multirow{5}{*}{ Over-all } & 1 & 3.44 & .435 & \multirow{5}{*}{94.350} & \multirow{5}{*}{.000} & \multirow{5}{*}{ Rejected } & \multirow{5}{*}{ Significant } \\
\hline & 2 & 3.30 & .536 & & & & \\
\hline & 3 & 3.51 & .928 & & & & \\
\hline & 4 & 3.29 & .513 & & & & \\
\hline & 5 & 3.50 & .498 & & & & \\
\hline
\end{tabular}

Table 11 showed the differences between the assessments of the two groups of respondents on the extent of integration of ICT in teaching with an overall t-value of 94.350 and sig. value of 000 and interpreted as significant which leads to reject the null hypothesis. The computed t-value and sig. value of each variable such as entry $(100.286, .000)$, adaptation $(78.189, .000)$, appropriation $(47.936, .000)$, adoption $(81.265, .000)$ and 
Extent of integration of the ICT in teaching at selected public elementary schools in the Division of Pasig City invention $(89.371, .000)$ reject the null hypothesis of no significant difference. These results show that there is significant difference between the assessments of the two groups (teachers and head teachers) of respondents on the extent of integration of ICT in teaching.

3.4 Difference between the extent of integration of teacher when grouped according to the teacher-profile

Table 12

Differences between the extent of integration of teacher when grouped according to the teachers' age

\begin{tabular}{|c|c|c|c|c|c|c|c|}
\hline $\begin{array}{c}\text { Extent of Integration } \\
\text { of Teacher }\end{array}$ & Age & Mean & SD & F-Value & Sig & $\begin{array}{c}\text { Decision } \\
\text { on Ho }\end{array}$ & Interpretation \\
\hline \multirow{3}{*}{ 1. Entry } & 25-below & 3.55 & .207 & \multirow{3}{*}{1.248} & \multirow{3}{*}{.275} & \multirow{3}{*}{ Accepted } & \multirow{3}{*}{ Not Significant } \\
\hline & $26-35$ & 3.48 & .484 & & & & \\
\hline & 36-above & 3.42 & .432 & & & & \\
\hline \multirow{3}{*}{ 2. Adaptation } & 25-below & 3.15 & .351 & \multirow{3}{*}{.711} & \multirow{3}{*}{.713} & \multirow{3}{*}{ Accepted } & \multirow{3}{*}{ Not Significant } \\
\hline & $26-35$ & 3.37 & .619 & & & & \\
\hline & 36-above & 3.30 & .520 & & & & \\
\hline \multirow{3}{*}{ 3. Appropriation } & 25-below & 3.70 & .321 & \multirow{3}{*}{1.906} & \multirow{3}{*}{.038} & \multirow{3}{*}{ Rejected } & \multirow{3}{*}{ Significant } \\
\hline & $26-35$ & 3.52 & .568 & & & & \\
\hline & 36-above & 3.49 & 1.040 & & & & \\
\hline \multirow{3}{*}{ 4. Adoption } & 25-below & 2.95 & .141 & \multirow{3}{*}{1.104} & \multirow{3}{*}{.363} & \multirow{3}{*}{ Accepted } & \multirow{3}{*}{ Not Significant } \\
\hline & $26-35$ & 3.22 & .636 & & & & \\
\hline & 36-above & 3.33 & .479 & & & & \\
\hline \multirow{3}{*}{ 5. Intervention } & 25-below & 3.63 & .345 & \multirow{3}{*}{1.738} & \multirow{3}{*}{.085} & \multirow{3}{*}{ Accepted } & \multirow{3}{*}{ Not Significant } \\
\hline & $26-35$ & 3.52 & .566 & & & & \\
\hline & 36-above & 3.49 & .486 & & & & \\
\hline \multirow{3}{*}{ Over-all } & 25-below & 3.40 & .199 & \multirow{3}{*}{1.533} & \multirow{3}{*}{.045} & \multirow{3}{*}{ Rejected } & \multirow{3}{*}{ Significant } \\
\hline & $26-35$ & 3.42 & .520 & & & & \\
\hline & 36-above & 3.41 & .454 & & & & \\
\hline
\end{tabular}

Table 12 discussed the differences between the extent of teachers' integration when grouped according to the teacher's age. It resulted to an overall F-value of 1.533 and sig. value of .045 that leads to reject the null hypothesis. Therefore, it concluded that there is a significant difference between extent of teachers' integration in terms of appropriation $(\mathrm{F}$-value $=1.906$, Sig $=.038)$ and their age. Meanwhile, it can also be noted that there is no significant difference between the teacher's age and the extent of integration of teacher in terms of entry $($ F-value $=1.248, \operatorname{Sig}=.275)$, adaptation $(F$-value $=.711, \operatorname{Sig}=.713)$, adoption $($ F-value $=1.104, \operatorname{Sig}=.363)$ and invention $(\mathrm{F}$-value $=1.738, \mathrm{Sig}=.085)$ thus rejecting the null hypothesis .

Table 13

Differences between the extent of integration of teacher when grouped according to the teachers' sex

\begin{tabular}{|c|c|c|c|c|c|c|c|}
\hline $\begin{array}{c}\text { Extent of } \\
\text { Integration of } \\
\text { Teacher }\end{array}$ & Sex & Mean & $\mathrm{SD}$ & F-Value & Sig & $\begin{array}{c}\text { Decision } \\
\text { on Ho }\end{array}$ & Interpretation \\
\hline \multirow{2}{*}{ 1. Entry } & Male & 3.49 & .465 & \multirow{2}{*}{35.239} & \multirow{2}{*}{.000} & \multirow{2}{*}{ Rejected } & \multirow{2}{*}{ Significant } \\
\hline & Female & 3.43 & .432 & & & & \\
\hline \multirow{2}{*}{ 2. Adaptation } & Male & 3.37 & .543 & \multirow{2}{*}{28.045} & \multirow{2}{*}{.000} & \multirow{2}{*}{ Rejected } & \multirow{2}{*}{ Significant } \\
\hline & Female & 3.29 & .536 & & & & \\
\hline \multirow{2}{*}{ 3. Appropriation } & Male & 3.52 & .591 & \multirow{2}{*}{21.015} & \multirow{2}{*}{.000} & \multirow{2}{*}{ Rejected } & \multirow{2}{*}{ Significant } \\
\hline & Female & 3.50 & .972 & & & & \\
\hline \multirow{2}{*}{ 4. Adoption } & Male & 3.38 & .520 & \multirow{2}{*}{28.273} & \multirow{2}{*}{.000} & \multirow{2}{*}{ Rejected } & \multirow{2}{*}{ Significant } \\
\hline & Female & 3.27 & .512 & & & & \\
\hline \multirow{2}{*}{ 5. Intervention } & Male & 3.65 & .545 & \multirow{2}{*}{32.716} & \multirow{2}{*}{.000} & \multirow{2}{*}{ Rejected } & \multirow{2}{*}{ Significant } \\
\hline & Female & 3.48 & .488 & & & & \\
\hline \multirow{2}{*}{ Over-all } & Male & 3.48 & .474 & \multirow{2}{*}{33.179} & \multirow{2}{*}{.000} & \multirow{2}{*}{ Rejected } & \multirow{2}{*}{ Significant } \\
\hline & Female & 3.40 & .457 & & & & \\
\hline
\end{tabular}

The differences between the extent of teachers' integration when grouped according to the teacher's sex defined in Table 12. With the overall F-value (33.179) and sig. value (.000) lower than the level of significance, 
Torres, M.

the null hypothesis is rejected thereby stating that there is a significant difference between the variables. There is no significant difference between the extent of integration of teacher in terms of entry (F-value $=35.239$, Sig $=.000)$, adaptation $($ F-value $=28.045, \mathrm{Sig}=.000)$, appropriation $($ F-value $=21.015, \mathrm{Sig}=.000)$, adoption $(\mathrm{F}$-value $=28.273, \mathrm{Sig}=.000)$ and invention $(\mathrm{F}$-value $=32.716, \mathrm{Sig}=.000)$ when grouped according to sex.

Table 14

Differences between the extent of integration of teacher according to the teachers' highest educational attainment

\begin{tabular}{|c|c|c|c|c|c|c|c|}
\hline $\begin{array}{c}\text { Extent of } \\
\text { Integration of } \\
\text { Teacher }\end{array}$ & $\begin{array}{c}\text { Highest Educational } \\
\text { Attainment }\end{array}$ & Mean & SD & $\begin{array}{c}\text { F-Val } \\
\text { ue }\end{array}$ & Sig & $\begin{array}{l}\text { Decision } \\
\text { on Ho }\end{array}$ & $\begin{array}{c}\text { Interpretatio } \\
\mathrm{n}\end{array}$ \\
\hline \multirow{5}{*}{ 1. Entry } & Doctorate Degree & 3.20 & .283 & \multirow{5}{*}{1.098} & \multirow{5}{*}{.368} & \multirow{5}{*}{ Accepted } & \multirow{5}{*}{$\begin{array}{l}\text { Not } \\
\text { Significant }\end{array}$} \\
\hline & Units in Doctorate & 3.44 & .509 & & & & \\
\hline & Master's Degree & 3.51 & .411 & & & & \\
\hline & Units in Master & 3.44 & .434 & & & & \\
\hline & Bachelor's Degree & 3.26 & .447 & & & & \\
\hline \multirow{5}{*}{ 2. Adaptation } & Doctorate Degree & 3.00 & .000 & \multirow{5}{*}{1.765} & \multirow{5}{*}{.072} & \multirow{5}{*}{ Accepted } & \multirow{5}{*}{$\begin{array}{l}\text { Not } \\
\text { Significant }\end{array}$} \\
\hline & Units in Doctorate & 3.50 & .570 & & & & \\
\hline & Master's Degree & 3.41 & .532 & & & & \\
\hline & Units in Master & 3.18 & .521 & & & & \\
\hline & Bachelor's Degree & 3.24 & .519 & & & & \\
\hline \multirow{5}{*}{ 3. Appropriation } & Doctorate Degree & 3.20 & .000 & \multirow{5}{*}{.816} & \multirow{5}{*}{.633} & \multirow{5}{*}{ Accepted } & \multirow{5}{*}{$\begin{array}{l}\text { Not } \\
\text { Significant }\end{array}$} \\
\hline & Units in Doctorate & 3.59 & .605 & & & & \\
\hline & Master's Degree & 3.71 & 1.300 & & & & \\
\hline & Units in Master & 3.28 & .541 & & & & \\
\hline & Bachelor's Degree & 3.47 & .421 & & & & \\
\hline \multirow{5}{*}{ 4. Adoption } & Doctorate Degree & 3.00 & .283 & \multirow{5}{*}{1.618} & \multirow{5}{*}{.106} & \multirow{5}{*}{ Accepted } & \multirow{5}{*}{$\begin{array}{l}\text { Not } \\
\text { Significant }\end{array}$} \\
\hline & Units in Doctorate & 3.51 & .575 & & & & \\
\hline & Master's Degree & 3.35 & .533 & & & & \\
\hline & Units in Master & 3.19 & .481 & & & & \\
\hline & Bachelor's Degree & 3.23 & .471 & & & & \\
\hline \multirow{5}{*}{ 5. Intervention } & Doctorate Degree & 3.20 & .000 & \multirow{5}{*}{1.855} & \multirow{5}{*}{.063} & \multirow{5}{*}{ Accepted } & \multirow{5}{*}{$\begin{array}{l}\text { Not } \\
\text { Significant }\end{array}$} \\
\hline & Units in Doctorate & 3.60 & .592 & & & & \\
\hline & Master's Degree & 3.61 & .455 & & & & \\
\hline & Units in Master & 3.38 & .515 & & & & \\
\hline & Bachelor's Degree & 3.48 & .473 & & & & \\
\hline \multirow{5}{*}{ Over-all } & Doctorate Degree & 3.12 & .000 & \multirow{5}{*}{1.533} & \multirow{5}{*}{.055} & \multirow{5}{*}{ Accepted } & \multirow{5}{*}{$\begin{array}{l}\text { Not } \\
\text { Significant }\end{array}$} \\
\hline & Units in Doctorate & 3.53 & .546 & & & & \\
\hline & Master's Degree & 3.52 & .477 & & & & \\
\hline & Units in Master & 3.30 & .428 & & & & \\
\hline & Bachelor's Degree & 3.34 & .364 & & & & \\
\hline
\end{tabular}

Table 14 demonstrated the differences between the extent of teacher's integration when grouped according to highest educational attainment of the respondents. The table shows that there is no significant difference between the variables resulting to an F-value of 1.533 and sig. value of .055 , thus accepting the null hypothesis.

There is no significant difference between the extent of integration of teacher in terms of entry $(\mathrm{F}-\mathrm{value}=$ $1.098, \mathrm{Sig}=.368)$, adaptation $(\mathrm{F}$-value $=1.765$, Sig $=.072)$, appropriation $($ F-value $=.816$, Sig $=.633)$, adoption $(\mathrm{F}$-value $=1.618, \mathrm{Sig}=.106)$ and invention $(\mathrm{F}$-value $=1.855, \mathrm{Sig}=.063)$ when grouped according to highest educational attainment. The assessment of the group of respondents were almost the same. They had a similar assessment on the extent of integration in terms of entry, adaptation, appropriation, adoption and intervention. Highest educational attainment of the respondents did not influence the extent of integration of ICT in teaching. 
Extent of integration of the ICT in teaching at selected public elementary schools in the Division of Pasig City

Table 15

Differences between the extent of integration of teacher according number of trainings/seminars attended

\begin{tabular}{|c|c|c|c|c|c|c|c|}
\hline $\begin{array}{l}\text { Extent of } \\
\text { Integration of } \\
\text { Teacher }\end{array}$ & $\begin{array}{l}\text { Teachers' } \\
\text { Number of } \\
\text { Trainings/ } \\
\text { Seminars } \\
\text { Attended } \\
\text { Related to } \\
\text { ICT }\end{array}$ & Mean & SD & F-Value & Sig & $\begin{array}{c}\text { Decision on } \\
\text { Ho }\end{array}$ & Interpretation \\
\hline \multirow{4}{*}{ 1. Entry } & $0-1$ & 3.31 & .418 & \multirow{4}{*}{2.793} & \multirow{4}{*}{.007} & \multirow{4}{*}{ Rejected } & \multirow{4}{*}{ Significant } \\
\hline & $2-3$ & 3.46 & .405 & & & & \\
\hline & $4-5$ & 3.32 & .469 & & & & \\
\hline & 6 and above & 3.74 & .329 & & & & \\
\hline \multirow{4}{*}{ 2. Adaptation } & $0-1$ & 3.27 & .549 & \multirow{4}{*}{1.386} & \multirow{4}{*}{.192} & \multirow{4}{*}{ Accepted } & \multirow{4}{*}{$\begin{array}{c}\text { Not } \\
\text { Significant }\end{array}$} \\
\hline & $2-3$ & 3.26 & .530 & & & & \\
\hline & $4-5$ & 3.15 & .545 & & & & \\
\hline & 6 and above & 3.68 & .335 & & & & \\
\hline \multirow{4}{*}{ 3. Appropriation } & $0-1$ & 3.50 & .512 & \multirow{4}{*}{1.503} & \multirow{4}{*}{.129} & \multirow{4}{*}{ Accepted } & \multirow{4}{*}{$\begin{array}{c}\text { Not } \\
\text { Significant }\end{array}$} \\
\hline & $2-3$ & 3.56 & 1.354 & & & & \\
\hline & $4-5$ & 3.28 & .515 & & & & \\
\hline & 6 and above & 3.70 & .405 & & & & \\
\hline \multirow{4}{*}{ 4. Adoption } & $0-1$ & 3.24 & .487 & \multirow{4}{*}{1.746} & \multirow{4}{*}{.076} & \multirow{4}{*}{ Accepted } & \multirow{4}{*}{$\begin{array}{c}\text { Not } \\
\text { Significant }\end{array}$} \\
\hline & $2-3$ & 3.21 & .472 & & & & \\
\hline & $4-5$ & 3.23 & .557 & & & & \\
\hline & 6 and above & 3.62 & .468 & & & & \\
\hline \multirow{4}{*}{ 5. Intervention } & $0-1$ & 3.57 & .486 & \multirow{4}{*}{1.077} & \multirow{4}{*}{.383} & \multirow{4}{*}{ Accepted } & \multirow{4}{*}{$\begin{array}{c}\text { Not } \\
\text { Significant }\end{array}$} \\
\hline & $2-3$ & 3.45 & .510 & & & & \\
\hline & $4-5$ & 3.27 & .449 & & & & \\
\hline & 6 and above & 3.88 & .305 & & & & \\
\hline \multirow{4}{*}{ Over-all } & $0-1$ & 3.38 & .411 & \multirow{4}{*}{2.225} & \multirow{4}{*}{.001} & \multirow{4}{*}{ Rejected } & \multirow{4}{*}{ Significant } \\
\hline & $2-3$ & 3.39 & .485 & & & & \\
\hline & $4-5$ & 3.25 & .460 & & & & \\
\hline & 6 and above & 3.72 & .290 & & & & \\
\hline
\end{tabular}

Table 15 conferred the differences between the extent of teacher's integration when grouped according to teachers' number of seminars/training attended related to ICT. The table shows a significant difference between the variables resulting in an F-value of 2.225 and sig. value of .001, thus rejecting the null hypothesis.

There is no significant difference between the extent of integration of teacher in terms of adaptation (F-value $=1.386, \mathrm{Sig}=.192)$, appropriation $($ F-value $=1.503, \mathrm{Sig}=.129)$, adoption $($ F-value $=1.746, \mathrm{Sig}=.076)$ and invention $(\mathrm{F}$-value $=1.077, \mathrm{Sig}=.383)$ when grouped according to highest educational attainment. However, when it comes to entry $(\mathrm{F}$-value $=2.793$, Sig $=.007)$, it leads to reject the null hypothesis which stated that there is a significant difference between the variables. In terms of number of trainings/seminars attended related to ICT they had a different degree of assessment.

\section{Table 16}

Summary of significant difference between the extent of integration of teacher according to the teacher-profile

\begin{tabular}{lcccc}
\hline \multicolumn{1}{c}{ Teacher-Profile } & F-Value & Sig & $\begin{array}{c}\text { Decision on } \\
\text { Ho }\end{array}$ & Interpretation \\
\hline 1.Age & 1.533 & .045 & Rejected & Significant \\
2.Sex & 33.179 & .000 & Rejected & Significant \\
3.Highest Educational Attainment & 1.533 & .055 & Accepted & Not Significant \\
4.Number of Trainings/Seminars & 2.225 & .001 & Rejected & Significant \\
Attended Related to ICT & & & & \\
\hline
\end{tabular}

Table 16 presented that there is significant difference between extent of integration of teacher when grouped according to the teacher's age, sex, and number of trainings/seminars attended regarding ICT. However, when it comes to highest educational attainment, there is no significant difference. 


\section{Conclusions and Recommendations}

The following conclusions were arrived based on the findings of the study.

The majority of the respondents were mature and old enough to handle their students. It also shows that since they are mature, they were confident and more experienced than the beginner teachers. The majority of the head teachers and teachers were females; thus, they were all guided by their maternal instinct in teaching their students. Most of the teachers considered Graduate School as part of their professional growth. They were all continuing their education for them to gain more knowledge about teaching. The teacher-respondents need to be encouraged to attend training/seminars regarding ICT for them to be more equipped and knowledgeable regarding the ICT integration in teaching.

The extent of integration of ICT as needed by the two groups of respondents classified as to entry, adaptation and appropriation rated as Agree. A typical entry-level teacher uses whole group activities, direct instruction and technology to support traditional instruction methods. While in terms of adoption and invention, it rated as Highly Agree. ICT was set up to close to and for the teacher's convenience and has become ever-present transparent part of curriculum. There is a significant difference between the assessments of the two groups of respondents on the extent of integration of ICT in teaching. There is a significant difference between the extent of teacher's integration when grouped according to the teacher's age, sex and seminars/training attended regarding ICT. However, when it comes to highest educational attainment, there is no significant difference.

Teacher education institutions should provide in-service training on the integration of ICT in teaching in order to improve the instructional delivery of the teachers and increase the level of ICT integration to instruction. Teacher education institutions should provide the necessary infrastructure, technical support, proper leadership, time and promote access to available facilities to encourage teachers to integrate ICT in teaching. Teacher educators should be encouraged to model and integrate ICT in teaching to serve as models to the pre-service teachers who would most probably adopt their pedagogies in their future classrooms. Encourage ICT integration in teaching not only in Educational Technology courses but to other teacher education courses as well to be able to give pre-service teachers a bigger exposure to ICT integration. Conduct trainings, seminars and workshops on integration of ICT in teaching to school administrators. Conducting such will ensure that they can provide proper guidance and support to their teachers. In the accreditation of schools, include these specific areas for evaluation: teacher's skill on integration of ICT in teaching. This will encourage or force teacher education institutions to adopt ICT integration.

Acknowledgements - The author takes pride in acknowledging and express gratitude to all the individuals that supported and gave her strength and guidance to write this piece of work. I also wish to thank all the teachers and head teachers for the effort and time. A huge thanks also to NAPICO Elementary School and Manggahan Elementary School for creating an environment friendly for bringing out the study. Lastly, the author wishes to announce that there is no conflict of interest in publishing this study.

\section{References}

Araiz, J. (2018). Profile and level of competence of information and communications technology (ICT) coordinators among secondary schools in the division of Davao del Sur. JPAIR Multidisciplinary Research, 32(1), 124-148. https://doi.org/10.7719/jpair. v32i1.579

Becuwe, H., Roblin, N. P., Tondeur, J., Thys, J., Castelein, E., and Voogt, J. (2017). Conditions for the successful implementation of teacher educator design teams for ICT integration: A Delphi study. https://doi.org/10.14742/ajet.2789

Berok, V. J. J., \& Yunus, M. M. (2019). Chasing the emerging trend of ICT: The challenges faced by ESL 
Extent of integration of the ICT in teaching at selected public elementary schools in the Division of Pasig City

teachers and their attitude in integrating ICT in rural schools of Tatau District. Journal of Information System and Technology Management, 4(13), 84-96. https://doi.org/10.35631/JISTM.413008

Bhatt, H. (2017). Effect of ICT skills development instructional program on technology integration beliefs and self-regulation of trainee teachers

Biddix, J. P., Chung, C. J., \& Park, H. W. (2016). Faculty use and perception of mobile information and communication technology (m-ICT) for teaching practices

Caluza, L. J. B. (2018). Predicting teachers' ICT competence in a Philippine university using J48 algorithm, information technology and computer education department, Leyte Normal University. https://doi.org/10.17485/ijst/2018/v11i7/119062

Catanuan, H. P. (2017). Information and communication technology (ICT) competencies of selected district II public elementary school teachers in the city of General Trias: Basis for ICT development program for teachers.

Chemwei, B., Kiboss, J. K., \& Njag, K. (2016). Relationship between teacher - educator characteristics and the integration of information and communication technologies in teaching and learning in teacher education institutions in Kenya

Chen, M., Zhou, C., Wu, D., Yang, W., \& Shi, Y. (2019). Research on the differences of K-12 mathematic teachers' ICT application level. https://doi.org/10.1109/EITT.2019.00030

Daling, R. F. (2018). Secondary School Teachers' Competency in Information and Communication Technology, Surigao del Sur State University- San Miguel Campus

Dela Rosa, J. (2016). Experiences, perceptions and attitudes on ICT integration: A case study among novice and experienced language teachers in the Philippines. International Journal of Education and Development using ICT, 12(3). Retrieved from https://www.learntechlib.org/p/174312/ 
Torres, $\mathrm{M}$.

136 Consortia Academia Publishing (A partner of Network of Professional Researchers and Educators) 